\title{
Does Innovation and Relational Learning Influence SME Performance? An Empirical Evidence from Pakistan
}

\author{
Muhammad Haroon Hafeez ${ }^{1}$, Mohd Noor Mohd Shariff ${ }^{1}$ \& Halim bin Mad Lazim ${ }^{2}$ \\ ${ }^{1}$ School of Business Management, Universiti Utara Malaysia, Sintok, Kedah, Malaysia \\ ${ }^{2}$ School of Technology Management and Logistics, Universiti Utara Malaysia, Sintok, Kedah, Malaysia \\ Correspondence: Muhammad Haroon Hafeez, School of Business Management, Universiti Utara Malaysia, \\ 06010 UUM Sintok, Kedah, Malaysia. Tel: 60-11-1250-7824. E-mail: haroonhafeez@bzu.edu.pk
}

Received: July 18, 2013 Accepted: August 22, 2013 Online Published: October 29, 2013

doi:10.5539/ass.v9n15p204

URL: http://dx.doi.org/ass.v9n15p204

\begin{abstract}
This paper reviews the literature in a thorough manner in a bid to propose a model proposing that Innovation (technological and non-technological) and Relational learning can greatly influence the performance of Small and Medium Enterprises (SMEs) in a developing country like Pakistan. On the basis of literature review, research hypotheses have been formulated. In order to test the hypotheses, Structural Equation Modeling (SEM) has been employed to analyze the study conducted in 352 SMEs in Pakistan. The proposed model leads to very useful insights as it proposes that SMEs must not ignore the importance of Innovation especially technological innovation and Relational learning in order to achieve higher performance. Results indicate that Technological Innovation and Relational Learning have a positive significant effect on firm performance; whereas the effect of non-technological innovation on firm performance has been found as insignificant. The paper concludes with the discussion of managerial implications and recommendations for future research.
\end{abstract}

Keywords: technological innovation, non-technological innovation, relational learning, SMEs performance, Pakistan

\section{Introduction}

SMEs are strategically important in many developing countries, particularly those located in the Asian region. In Malaysia, SMEs represent $99.2 \%$ businesses, account for $56.4 \%$ of employment and contribute $32 \%$ of GDP; In Japan, SMEs represent $99.7 \%$ of businesses, provide $71 \%$ of employment and contribute $55.3 \%$ of GDP; In China, SMEs represent $99 \%$ of total business establishments, account for $75 \%$ of employment and contribute $56 \%$ of GDP; In Indonesia, the corresponding figures are 99.7\%, 99.6\% and 57\% respectively (Rosman \& Rosli, 2012).

Similarly in South Asia, SMEs contribute immensely towards economic growth and development. In Bangladesh, SMEs contribute $50 \%$ to industrial GDP and employ $82 \%$ of industrial sector employees. In Nepal, SMEs represents almost $98 \%$ of businesses and contribute $63 \%$ of the value-added segment. In India, SMEs' contribute $30 \%$ of GDP. In the same manner, SMEs are making significant contributions in Pakistan's economic development. In Pakistan, SMEs represent about $99 \%$ of total business establishments. They are mostly dealing in wholesale and retailing and restaurant and hotel (53\%), Social and Personnel services (22\%) and manufacturing (20\%). These SMEs are accounting for $30 \%$ of annual gross domestic product (GDP) of the country, employment of $80 \%$ of non-agricultural labor force, $25 \%$ of total exports and $35 \%$ of value added manufacturing (Hussain, Si, Xie \& Wang, 2010).

It has been identified that despite of magnanimous economic support and contribution towards development, the performance of SMEs remains below expectations in the developing countries (Arinaitwe, 2006). The factors contributing towards low performance comprise of unfavorable economic conditions, inconsistent public policies, lack of infrastructural support, financial constraints, mounting operating costs and corruption (Oboh, 2002; Okpara, 2000; Wale-Awe, 2002). In Pakistan, the situation is not very different. SMEs are experiencing a low growth trap (Khawaja, 2006). In terms of performance, SMEs in Pakistan are struggling for longevity and sustainability of their businesses. It is evident from statistical facts that $19 \%$ of SMEs are less than 5 years old and only $4 \%$ of the firms are able to operate for more than 25 years (Hussain et al., 2010). 
The review of literature as discussed before has revealed a number of issues associated with firm performance. Some of those issues such as financing, government regulations, entrepreneurial skills and working conditions of SMEs have received considerable attention from the researchers and have been studied in various contexts. It is observed that Relational Learning and Innovation are a few contemporary issues highlighted in the recent studies.

Khalique, Shaari, Isa and Ageel (2011) argued that the economies of developed countries are moving from production based economies to knowledge based economies. So there is a dire need to explore and exploit the available knowledge resources from within as well as from the environment. Ramezan (2011) also emphasized that organizational knowledge is the foundation of intellectual capital therefore, it is considered central to the organizational capabilities to perform well. Among the best sources of knowledge include the competing firms, firms in value chain, research institutes, universities and scientific laboratories (Pedler et al., 1997; Bapuji \& Crossan, 2004; Chiva, Alegre \& Lapiedra, 2007). In previous studies (Tanvir, Rizvi \& Riaz, 2012; Mansoor, 2011) the researchers have identified that lack of innovation is among the causes of declining performance in SMEs of Pakistan. In Pakistan there is very limited research if any with respect to innovation (Hanif \& Manarvi, 2009) and organizational learning (Malik, Khan, Bhutto \& Ghouri, 2011) in the context of SMEs. Therefore, this study intends to focus on these contemporary issues with reference to performance of SMEs in Pakistan.

\section{Proposed Model and Literature Review}

The theoretical base of this paper is founded by reviewing the literature. In the literature, causal linkages have been identified between Innovation, Relational Learning and SMEs performance. Figure 1 elaborates all the linkages in a sequential manner.

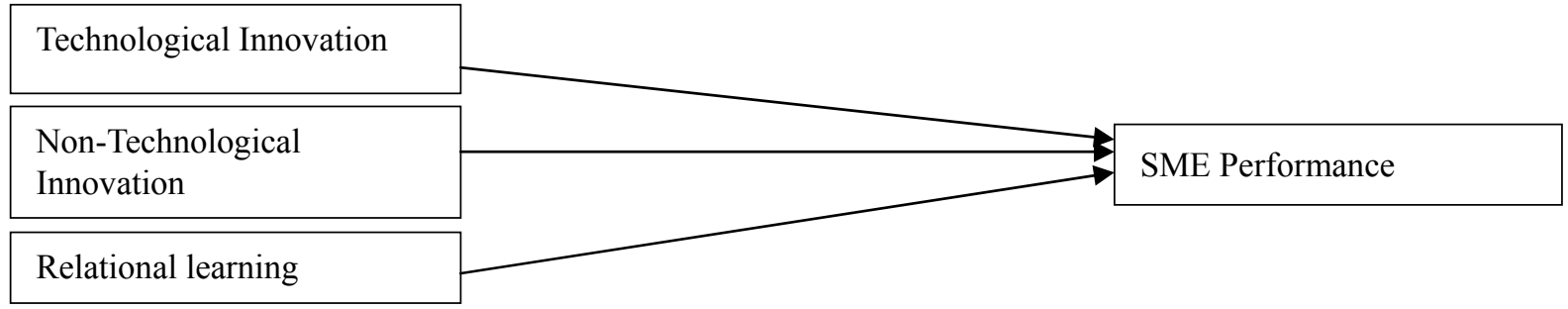

Figure 1. Proposed model

Figure1 proposes that SMEs performance can largely be influenced by Technological Innovation, Non-Technological Innovation and Relational Learning. The rationale for the linkages shown in the figure 1 is grounded in the literature as discussed below.

\subsection{Influence of Innovation on SMEs Performance}

Innovation is linked with a variety of issues concerning organizational processes, learning, and capabilities (Freeman \& Soete, 1997). Kanter (1983) defined innovation as the creation, adoption, and execution of novel ideas, processes, products, or services. According to researchers in the field of business management, ability to innovate is the most fundamental determinant of firm performance (Mone, McKinley \& Barker, 1998). Undeniably, this academic proposition has been empirically verified by numerous studies (Deshpande, Farley \& Webster, 1993; Baldwin \& Johnson, 1996; Capron, 1999; Danneels \& Kleinschmidt, 2001; Salavou, 2002; Calantone, Cavusgil \& Zhao, 2002; Klomp \& van Leeuwen, 2001).

In previous literature, Innovation and improvement in performance are commonly found in SMEs (O'Regan, Ghobadina \& Sims, 2006; Subrahmanya, 2005). Greater flexibility enables small firms to be more innovative and perform higher, as they are in a better position to respond to market changes and have shorter and faster decision chains (less bureaucratic inertia). SMEs can gain competitive advantages by dominating market niches through innovation efficiency (Hafeez, Shariff \& Lazim, 2012). They have more capacity for customization and possess the ability to learn faster and adapt routines and strategies to leverage firm performance. There are several studies conducted in SMEs to see their innovation practices. Studies conducted by Hyvarinen (1990), McAdam, Armstrong and Kelly, (1998), Avermaete et al. (2004), Freel (2005), Yap, Chai, and Lemaire (2005), Allocca and Kessler (2006), de Jong and Vermuelen (2006), Oke, Burke and Myers (2007), and Dibrell, Davis and Craig (2008) can be considered as a few examples of these researches carried out in SMEs.

Most studies on innovation are performed in developed countries like Canada (Branzei \& Vertinsky, 2006), United States of America (Wolf \& Pett, 2006; Allocca \& Kessler, 2006), Netherlands (de Jong \& Vermeulen, 
2006), England (Edwards, Delbridge \& Munday, 2005), Newzealand (Clark, 2010) and Turkey (Ar \& Baki, 2011), and resultantly, policy makers from developing nations often analyze those findings when designing policy measures (Radas \& Bozic, 2009). However, the theoretical models formulated in the context of developed countries may not be applied or replicated in the context of a developing country (Najib \& Kiminami, 2011).

Most of previous studies on innovation have emphasized on technological innovations. A large number of studies have emphasized on product and process innovation in SMEs. Prajogo, Power and Sohal (2004), Wang \& Ahmed (2004), Avermaete et al. (2004), Leiponen (2005), Freel (2005) and Ar \& Baki (2011) are some examples in this regard. Product/service innovation is "the novelty and meaningfulness of new products introduced to the market in a timely fashion" (Wang \& Ahmed, 2004, p. 304). Process innovation is the "introduction of new production methods, new management approaches, and new technology that can be used to improve production and management processes" (Wang \& Ahmed, 2004, p. 305). There are very limited studies that have examined the impact of non-technological dimensions of innovation such as market/marketing innovations and administrative/managerial innovations (North \& Smallbone, 2000; Weerawardena, 2003) on firm performance. This study would add to the body of knowledge by examining the impact of both technological as well as non-technological dimensions of innovation on SME performance.

\subsection{Influence of Relational Learning on SMEs Performance}

The literature review has revealed wide range of definitions of organizational learning. According to Cyert and March (1963) and Hedberg (1981) learning refers to any change in the organization's operations that sustains or enhances performance. According to Fiol and Lyles (1985) learning can be defined as "the process of improving actions through better knowledge and understanding" (p. 803). In general, organizational learning refers to acquiring, assimilating and disseminating internal and external knowledge to update firms' knowledge about its surrounding environment and utilize that knowledge to enhance firm performance.

Relational learning is a dimension of organizational learning that takes place through neighboring firms and networks. Rothwell (1989) and Dodgson (1990) studied the inter-firm networking and relational aspects of learning and signified the importance of linkages with other firms in the industry, research institutes such as scientific laboratories and universities in order to effectively respond to changing environment. Past studies have emphasized on the salience of relational learning, networking and collaborative linkages with external institutes and skilled competitors in order to be more innovative and responsive to dynamic and competitive environments (Mody, 1993; Shan, 1990; Lee, Lee \& Pennings, 2001). A number of researchers have signified the importance of interacting with external actors (such as suppliers, customers, competitors, research institutes, universities and scientific laboratories) that can directly or indirectly influence organizational performance (Pedler et al., 1997; Popper \& Lipshitz, 2000; Bapuji \& Crossan, 2004; Chiva et al., 2007).

To conclude, the major goal of organizational learning is to alter and transform firm attitude and behavior in order to augment performance in terms of productivity and competitiveness, permitting the firm to achieve sales growth; attract, sustain and broaden its customer base. Furthermore, fast learning organizations boost their strategic competence, leading them towards securing and sustaining competitive advantage.

\section{Research Hypotheses}

On the basis of aforementioned literature review, following researches hypotheses have been formulated:

H1: Technological Innovation has a significant positive effect on SME Performance.

H2: Non-Technological Innovation has a significant positive effect on SME Performance.

H3: Relational Learning has a significant positive effect on SME Performance.

\section{Methodology}

The sampling unit of study was manufacturing, trading and service providing SMEs in Pakistan. 1500 SMEs were approached. 352 showed willingness to be surveyed. Owners/Managers of SMEs were interviewed using a structured questionnaire. Questionnaire items for Innovation (Technological \& Non-Technological) have been adapted and modified from Weerawardena (2003), and Wang and Ahmad (2004).Questionnaire items for Relational Learning have been adapted and modified from Pedler et al. (1997) and Chiva et al. (2007). Questionnaire Items for SME Performance have been adapted from widely cited research work by Gupta and Govindarajan (1984). Measurement of construct is demonstrated in table 1, which elaborates the items that comprise a construct along with the corresponding mean values for each individual item as well as for the overall construct. Seven-point likert type scale has been used for measurement of all items. Structural Equation Modeling technique using AMOS 20 with maximum likelihood estimation has been employed to analyze the 
data. The measurement model was estimated using confirmatory factor analysis (CFA) to test reliability and validity of the measurement model, and the structural model was also analyzed to examine the model fit results of the proposed model.

Table 1. Measurement of constructs

\begin{tabular}{llll}
\hline Constructs & Items & Mean & Cronbach alpha \\
\hline Technological Innovation & & $\mathbf{4 . 5 2}$ & $\mathbf{0 . 8 2 1}$
\end{tabular}

Product Innovation

Process Innovation

\section{Non-Technological Innovation}

Marketing Innovation

Managerial Innovation

Relational Learning

SME Performance
(PDI1) Product innovations introduced by our firm during the last three years have been extensive

(PDI2) Our new products and services are often perceived by our customers as highly innovative

(PDI3) Product improvements have been mainly radical in nature

(PRI1) Process innovations introduced by our firm during the last three years have been extensive

(PRI2) Our production processes are often perceived by our customers as highly innovative

(PRI3) Process improvements have been mainly radical in nature

4.66

4.16

4.64

0.839

(MKI1) Marketing innovations introduced by our firm during the last three years have been extensive

(MKI2) Our marketing methods are often perceived by our customers as very innovative

(MKI3) Marketing innovations have been mainly radical in nature

(MNI1) Managerial innovations introduced by our firm during the last three years have been extensive

(MNI2) Our managerial practices are often perceived by our employees as very Innovative

(MNI3) Managerial innovations have been mainly radical in nature

4.94

0.859

(IEE1) It is part of the work of all staff to collect, bring back and report information about what is going on outside the firm

(IEE2) There are systems and procedures for receiving, collating and sharing information from outside the firm

(IEE3) Employees are encouraged to interact with the suppliers, customers, competitors, marketing research firms, technological institutes and universities and government departments.

(IEE4) Our firm frequently collects information about changes in external environment (suppliers, customers, competitors).

(IEE5) Our firm extensively integrates external environment information to bring innovations

4.41

0.841

(P1) Sales Growth Rate in last three years

4.58

(P2) Market Share in last three years $\quad 3.95$

(P3) Operating Profits in last three years 4.50

(P4) Return on Investment in last three years $\quad 4.62$ 


\section{Results and Discussion}

Demographic characteristics of the respondents are presented in Table 2, which shows that firms have diverse characteristics in terms of age, size, scope and status of business. In terms of age, the majority of firms (73.6\%) had been operating for 1-20 years. With respect to business activity, $84.7 \%$ firms were manufacturing firms. In terms of size, almost $60 \%$ of the firms had 1-20 permanent employees. The amount of capital invested in the business ranged from less than two million Pakistan rupees to 40 million Pakistan rupees. A large number of respondents (47.2\%) refused to disclose the information about capital investment in the business as they consider it as confidential information. In terms of status of business, $76.4 \%$ of the firms stated that their business is maintaining a status quo position or declining; whereas, $23.6 \%$ stated that their business is growing well. With respects to scope of business, majority of firms (70\%) are involved in exporting their goods to other countries; whereas $30 \%$ of the firms have focused solely on dealing in local markets.

Table 2. Sample characteristics $(n=352)$

\begin{tabular}{|c|c|c|c|}
\hline Demographic Characteristics & Frequency & Percent (\%) & Cumulative (\%) \\
\hline \multicolumn{4}{|l|}{ Age of Business } \\
\hline $1-5$ years & 51 & 14.5 & 14.5 \\
\hline $6-10$ years & 84 & 23.9 & 38.4 \\
\hline $11-15$ years & 54 & 15.3 & 53.7 \\
\hline $15-20$ years & 70 & 19.9 & 73.6 \\
\hline$>20$ years & 93 & 26.4 & 100 \\
\hline \multicolumn{4}{|l|}{ Major Business Activity } \\
\hline Manufacturing & 298 & 84.7 & 84.7 \\
\hline Servicing & 8 & 2.3 & 87 \\
\hline Trading & 46 & 13 & 100 \\
\hline \multicolumn{4}{|l|}{ Number of Employees } \\
\hline 1-10 Employees & 129 & 36.6 & 36.6 \\
\hline 11-20 Employees & 79 & 22.4 & 59.1 \\
\hline 21-50 Employees & 63 & 17.9 & 77 \\
\hline 51-80 Employees & 29 & 8.2 & 85.2 \\
\hline 81-100 Employees & 51 & 14.5 & 99.7 \\
\hline Refused to respond & 1 & 0.3 & 100 \\
\hline \multicolumn{4}{|c|}{ Capital Invested (Pakistan Rupees) } \\
\hline$<2$ Million & 12 & 3.4 & 3.4 \\
\hline 2-10 Million & 86 & 24.4 & 27.7 \\
\hline 11-20 Million & 27 & 7.7 & 35.4 \\
\hline 21-30 Million & 18 & 5.1 & 40.5 \\
\hline 31-40 Million & 43 & 12.2 & 52.7 \\
\hline Refused to respond & 166 & 47.2 & 100 \\
\hline \multicolumn{4}{|l|}{ Status of Business } \\
\hline Growing & 83 & 23.6 & 23.6 \\
\hline Stable & 146 & 41.5 & 65.1 \\
\hline Declining & 123 & 34.9 & 100 \\
\hline \multicolumn{4}{|l|}{ Scope of Business } \\
\hline Exports only & 186 & 52.8 & 52.8 \\
\hline Local sales only & 103 & 29.3 & 82.1 \\
\hline Both Exports and Local sales & 63 & 17.9 & 100 \\
\hline
\end{tabular}




\subsection{Reliability and Validity}

In order to verify the reliability and validity, confirmatory factor analysis has been conducted as exhibited in Table 3 which summarizes the results of internal reliability using Cronbach's alpha in order to verify the unidimensionality. The obtained alpha values ranged from 0.814 to 0.859 , surpassing the acceptable threshold level of 0.70 recommended by Nunnally and Bernstein (1994). Furthermore, convergent validity was also accessed for constructs as shown in Table 3. The factor loading for all items is in excess of suggested cut-off level of 0.6 (Chin, Gopal \& Salisbury, 1997). Composite reliability of all latent constructs ranges from 0.817 to 0.860 which are well above the acceptable level 0.7 (Hair, Anderson \& Tatham, 1998). The average variances extracted, reflecting the overall amount of variance in the indicators accounted for by the latent construct range from 0.53 and 0.57 , surpassing acceptable threshold level of 0.5 (Hair et al., 1998). Moreover, discriminant validity refers to the extent to which the measures of various concepts are distinct. Discriminant validity is determined by comparing the squared correlations between constructs and variance extracted for a construct (Fornell \& Larcker, 1981). The results indicated that the square correlations for every construct is lesser than the average variance extracted by the indicators measuring that construct, as can be seen in Table 4, verifying that the measure has adequate discriminant validity. In summary, the measurement model has confirmed adequate reliability, convergent validity, and discriminant validity.

The following measured indices were assessed for the overall model fit. The observed normed v2 for measurement model was $1.881(\mathrm{v} 2=212.606, \mathrm{df}=113)$ which is lesser than 3 as suggested by Bagozzi and Yi (1988). Other fit indexes also indicate good fit for the measurement model. The adjusted goodness-of-fit index (AGFI) is 0.913 , which surpasses the suggested threshold level of 0.8 (Chau \& $\mathrm{Hu}, 2001$ ). The non-normed fit index (NNFI) is 0.956 and comparative fit index (CFI) is 0.963 , higher than the 0.9 suggested by Bagozzi and Yi (1988). The root mean square error of approximation (RMSEA) is 0.050 , exceeding the suggested cut-off value of 0.08 proposed by Browne and Cudeck (1993). The amalgamation of these results confirms that the established measurement model fits the data well.

Table 3. Results of CFA for measurement model

\begin{tabular}{|c|c|c|c|c|c|}
\hline \multirow{2}{*}{ Constructs } & \multirow{2}{*}{ Items } & \multirow{2}{*}{$\begin{array}{l}\text { Internal Reliability } \\
\text { Cronbach alpha }\end{array}$} & \multicolumn{3}{|c|}{ Convergent Validity } \\
\hline & & & Factor Loadings & Composite Reliability & AVE \\
\hline \multirow[t]{4}{*}{ Technological Innovation } & PRI1 & 0.814 & 0.719 & 0.817 & 0.53 \\
\hline & PRI2 & & 0.774 & & \\
\hline & PDI2 & & 0.723 & & \\
\hline & PDI3 & & 0.686 & & \\
\hline \multirow{4}{*}{$\begin{array}{ll}\text { Non } & \text { Technological } \\
\text { Innovation } & \end{array}$} & MKI2 & 0.837 & 0.772 & 0.836 & 0.56 \\
\hline & MKI3 & & 0.706 & & \\
\hline & MNI2 & & 0.786 & & \\
\hline & MNI3 & & 0.73 & & \\
\hline \multirow[t]{5}{*}{ Relational Learning } & IEE1 & 0.859 & 0.718 & 0.860 & 0.55 \\
\hline & IEE2 & & 0.746 & & \\
\hline & IEE3 & & 0.74 & & \\
\hline & IEE4 & & 0.737 & & \\
\hline & IEE5 & & 0.773 & & \\
\hline \multirow[t]{4}{*}{ SME Performance } & $\mathrm{P} 1$ & 0.841 & 0.768 & 0.843 & 0.57 \\
\hline & $\mathrm{P} 2$ & & 0.671 & & \\
\hline & P3 & & 0.801 & & \\
\hline & P4 & & 0.784 & & \\
\hline
\end{tabular}

Notes: All the loadings are significant at the 0.001 level of significance.

a: $\mathrm{CR}=(\Sigma \text { factor loading })^{2} /\left\{(\Sigma \text { factor loading })^{2}\right)+\Sigma$ (variance of error $\left.)\right\}$

b: AVE $=\Sigma(\text { factor loading })^{2} /(\Sigma \text { (factor loading })^{2}+\Sigma($ variance of error $\left.)\right\}$ 
Table 4. Discriminant validity

\begin{tabular}{lllll}
\hline Constructs & 1 & 2 & 3 & 4 \\
\hline 1) Firm Performance & 0.755 & & & \\
2) Relational Learning & 0.517 & 0.743 & & \\
3) Non Technological Innovation & 0.394 & 0.554 & 0.748 & \\
4) Technological Innovation & 0.385 & 0.397 & 0.708 & 0.728
\end{tabular}

Note: Diagonal values represent the square root of the average variance extracted while the off diagonal values represent the correlations among the latent constructs.

\subsection{Structural Model Results}

Results of structural model are shown in figure 2 which exhibits the causal linkages and fit statistics for structural model. Overall, the structural model displayed a good fit with the data, compared with the suggested fit criteria (Bagozzi \& Yi, 1988; Chau \& Hu, 2001; Browne \& Cudeck, 1993).

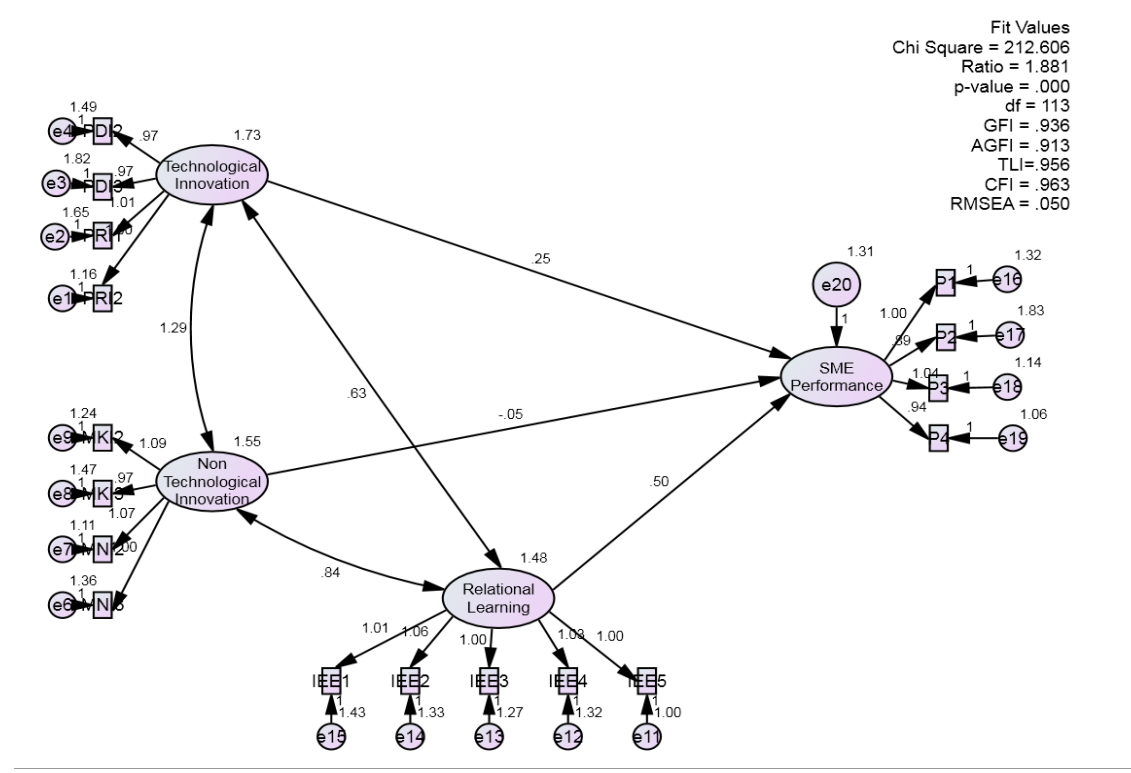

Figure 2. Structural model

On the basis of results with reference to internal reliability, convergent validity, discriminant validity and over all model fit, the decisions regarding hypothesized effects are given in table 5.

Table 5. Research findings

\begin{tabular}{clllll}
\hline Hypothesized Effect & & $\begin{array}{l}\text { Path } \\
\text { Coefficient }\end{array}$ & $\begin{array}{l}\mathrm{p} \\
\text { Value }\end{array}$ & $\begin{array}{l}\mathrm{t} \\
\text { Value }\end{array}$ & Decision \\
\hline H1: & $\begin{array}{l}\text { Technological Innovation has a positive } \\
\text { significant effect on Firm performance }\end{array}$ & $0.254^{*}$ & $.037^{*}$ & 2.081 & Supported \\
H2: & $\begin{array}{l}\text { Non Technological Innovation has a positive } \\
\text { significant effect on Firm performance } \\
\begin{array}{l}\text { Relational Learning has a positive significant } \\
\text { effect on Firm performance }\end{array}\end{array}$ & -0.49 & 0.733 & -0.341 & $\begin{array}{l}\text { Not } \\
\text { Supported }\end{array}$ \\
H3: & $0.503 * * *$ & 0.000 & 5.775 & Supported \\
\hline$* * *: p<0.001 ; * *: p<0.01 ; *: p<0.05$ & & & &
\end{tabular}

\section{Discussion and Conclusion}

This study presents an integrated multidimensional framework by integrating two distinct literature streams from innovation, and organizational learning perspective and analyzes their combined associated impact on firm performance in SMEs in Pakistan. It is anticipated that this study would be regarded as among pioneer studies 
that would examine the impact of Innovation, relational learning on SMEs performance in Pakistan. The study provides practical implications to owners/managers of SMEs regarding the importance of innovation and relational learning in SMEs. Results indicate that it is of utmost importance for SMEs to innovate especially in terms of introducing new products and updating their manufacturing processes in order to boost their performance. As the results demonstrate the positive significant relationship between technological innovation and performance, study is in line with the findings of previous studies such as Prajogo, Power and Sohal (2004), Avermaete et al. (2004), Leiponen (2005), Freel (2005) and Ar \& Baki (2011) highlighting the critical significance of technological innovations. Similarly study shows consistent results with past studies (Pedler et al., 1997; Chiva et al., 2007) indicating a direct influence of relational learning and performance. It signifies that in order to succeed SMEs must exploit the knowledge resources of and strategically learn from their neighboring firms, business partners, competitors, research firms, universities, scientific laboratories, and government agencies. Therefore, the study demands the SMEs to follow an innovation led and relational learning driven path to superior performance. However study provides food for thought for upcoming researchers to investigate the underlying reasons of insignificant effect of non-technological innovation on firm performance. Longitudinal studies can also be conducted in SMEs to investigate the impact of non-technological innovation on performance over the years. Similar studies can be conducted in other developing countries and cross countries results can be compared for generalizing the findings.

\section{References}

Allocca, M. A., \& Kessler, E. H. (2006). Innovation speed in small and medium enterprises. Creativity and Innovation Management, 15(3), 270-295. http://dx.doi.org/10.1111/j.1467-8691.2006.00389.x

Ar, I. M., \& Baki, B. (2011). Antecedents and performance impacts of product versus process innovation: Empirical evidence from SMEs located in Turkish science and technology parks. European Journal of Innovation Management, 14(2), 172-206. http://dx.doi.org/10.1108/14601061111124885

Arinaitwe, S. K. (2006). Factors constraining the growth and survival of small Scale businesses. A Developing Countries Analysis. Journal of American Academy of Business, 8(2), 167-179.

Avermaete, T., Viaene, J., Morgan, E. J., Pitts, E., Crawford, N., \& Mohon, D. (2004). Determinants of product and process innovation in small food manufacturing firms. Trends in Food Science and Technology, 15, 474-483. http://dx.doi.org/10.1016/j.tifs.2004.04.005

Bagozzi, R. P., \& Yi, Y. Y. (1988). On the evaluation of structural equation model. Journal of Academy of Marketing Science, 16(1), 74-94. http://dx.doi.org/10.1007/BF02723327

Baldwin, J. R., \& Johnson, J. (1996). Business strategies in more and less innovative firms in Canada. Research Policy, 25(5), 785-804. http://dx.doi.org/10.1016/0048-7333(95)00875-6

Bapuji, H., \& Crossan, M. (2004). From raising questions to providing answers: reviewing organizational learning research. Management Learning, 35(4), 397-417. http://dx.doi.org/10.1177/1350507604048270

Branzei, O., \& Vertinsky, I. (2006). Strategic pathways to product innovation capabilities in SMEs. Journal of Business Venturing, 21, 75-105. http://dx.doi.org/10.1016/j.jbusvent.2004.10.002

Browne, M. W., \& Cudeck, R. (1993). Alternative ways of assessing model fit. Newbury Park: Sage Publications.

Calantone, R. J., Cavusgil, S. T., \& Zhao, Y. (2002). Learning orientation, firm innovation capability, and firm performance. Industrial Marketing Management, $\quad 31, \quad 515-524$. http://dx.doi.org/10.1016/S0019-8501(01)00203-6

Capron, L. (1999). The long-term performance of horizontal acquisitions. Strategic Management Journal, 20, 987-1018. http://dx.doi.org/10.1002/(SICI)1097-0266(199911)20:11<987::AID-SMJ61>3.0.CO;2-B

Chau, P. Y. K., \& Hu, P. J. H. (2001). Information technology acceptance by individual professional: a model $\begin{array}{llll}\text { comparison } \quad \text { approach. } & \text { Decision } & \text { 32(4), } & \text { 699-719. }\end{array}$ http://dx.doi.org/10.1111/j.1540-5915.2001.tb00978.x

Chin, W. W., Gopal, A., \& Salisbury, W. D. (1997). Advancing the theory of adaptive structuration: the development of a scale to measure faithfulness of appropriation. Information Systems Research, 8(4), 342-367. http://dx.doi.org/10.1287/isre.8.4.342

Chiva, R., Alegre, J., \& Lapiedra, R. (2007). Measuring organizational learning capability among the workforce. International Journal of Manpower, 28(3), 224-242. http://dx.doi.org/10.1108/01437720710755227

Clark, D. N. (2010). Innovation management in SMEs: Active innovators in New Zealand. Journal of Small Business and Entrepreneurship, 23(4), 601-619. http://dx.doi.org/10.1080/08276331.2010.10593504

Cyert, R. M., \& March, J. G. (1963). A behavioural theory of the firm. Englewood Cliffs, NJ: Prentice Hall.

Danneels, E., \& Kleinschmidt, E. J. (2001). Product innovativeness from the firm's perspective: its dimensions and their relation with project selection and performance. The Journal of Product Innovation Management, 18(6), 357-373. http://dx.doi.org/10.1016/S0737-6782(01)00109-6

de Jong, J. P. J., \& Vermeulen, P. A. M. (2006). Determinants of Product Innovation in Small Firms. International Small Business Journal, 24(6), 587-609. http://dx.doi.org/10.1177/0266242606069268 
Deshpande, R., Farley, J. U., \& Webster, J. (1993). Corporate culture, customer orientation and innovativeness in Japanese firms: A Quadrad analysis. Journal of Marketing, 57(1), 23-37. http://dx.doi.org/10.2307/1252055

Dibrell, C., Davis, P. S., \& Craig, J. (2008). Fueling innovation through information technology in SMEs. $\begin{array}{lllll}\text { Journal of Small } & \text { Business } & \text { Management, } & \text { 46(2), }\end{array}$ http://dx.doi.org/10.1111/j.1540-627X.2008.00240.x

Dodgson, M. (1990). Technology strategy in small and medium-sized firms. In Z. J. Acs \& D. B. Adretsch (Eds.), The economics of small firms: a European perspective (pp. 157-167). Boston, MA: Kluwer Academic Publishers. http://dx.doi.org/10.1007/978-94-015-7854-7_10

Edwards, T., Delbridge, R., \& Munday, M. (2005). Understanding Innovation in Small and Medium Enterprises: A Process Manifest. Technovation, 25, 1119-1127. http://dx.doi.org/10.1016/j.technovation.2004.04.005

Fiol, C. M., \& Lyles, M. A. (1985). Organizational learning. Academy of Management Review, 10, 803-813.

Fornell, C., \& Larcker, D. F. (1981). Evaluating structural equation models with unobservable variables and measurement error. Journal of Marketing Research, 18(1), 39-50. http://dx.doi.org/10.2307/3151312

Freel, M. S. (2005). Patterns of innovation and skills in small firms. Technovation, 25(2), $123-134$. http://dx.doi.org/10.1016/S0166-4972(03)00082-8

Freeman, C., \& Soete, L. (1997). The economics of industrial innovation (3rd ed.). London: Pinter.

Gupta, A. K., \& Govindarajan, V. (1984). Business unit strategy and managerial characteristics and business unit effectiveness at strategy implementation. Academy of Management Review, 27(1), 25-41. http://dx.doi.org/10.2307/255955

Hafeez, M. H., Shariff, M. N. M., \& Lazim, H. M. (2012). Relationship between Entrepreneurial Orientation, Firm Resources, SME Branding and Firm's Performance: Is Innovation the Missing Link? American Journal of Industrial and Business Management, $2(4), \quad 153-159$. http://dx.doi.org/10.4236/ajibm.2012.24020

Hair, J. F., Anderson, R. L., \& Tatham, W. C. (1998). Multivariate Data Analysis with Reading. Upper Saddle River, NJ: Prentice-Hall.

Hanif, A., \& Manarvi, I. A. (2009, July). Influence of quality, innovation and new product/services design on small and medium enterprises. Proceedings of the World Congress on Engineering, London, U.K.

Hedberg, B. (1981). How organizations learn and unlearn. In P. C. Nystrom \& W. H. Starbuck (Eds.), Handbook of Organizational Design. New York: Oxford University Press.

Hussain, I., Si, S., Xie, X. M., \& Wang, L. (2010). Comparative study on impact of internal and external CFFs on SMEs. Journal of Small Business and Entrepreneurship, 23(4), 637-648. http://dx.doi.org/10.1080/08276331.2010.10593506

Hyvarinen, L. (1990). Innovativeness and its indicators in small and medium-sized industrial enterprises. International Small Business Journal, 9(1), 64-79.

Kanter, R. M. (1983). When a thousand flowers bloom: structural, collective and social conditions for innovation in organization. In R. Swedberg (Ed.), Entrepreneurship: The Social Science View (pp. 167-210). New York: Oxford University Press Inc.

Khalique, M., Shaari, J. A. N., Isa, A. H. M., \& Ageel, A. (2011). Role of intellectual capital on the organizational performance of electrical and electronic SMEs in Pakistan. International Journal of Business Management, 6(9), 253-257. Retrieved February, 11, 2013, from http:/www.ccsenet.org/ijbm

Khawaja, S. (2006). Unleashing the potential of the SME sector with a focus on productivity improvements. Pakistan Development Forum. Retrieved February 11, 2013, from http://siteresources.worldbank.org/PAKISTANEXTN/Resources/2930511147261112833/Session-3-2.pdf

Klomp, L., \& van Leeuwen, G. (2001). Linking innovation and firm performance: A new approach. International Journal of the Economics of Business, 8(3), 343-364. http://dx.doi.org/10.1080/13571510110079612

Lee, C., Lee, K., \& Pennings, J. M. (2001). Internal capabilities, external networks, and performance: a study on technology-based ventures. Strategic Management Journal, 2, 615-640. http://dx.doi.org/10.1002/smj.181

Leiponen, A. (2005). Skills and innovation. International Journal of Industrial Organization, 23(5-6), $303-323$. http://dx.doi.org/10.1016/j.ijindorg.2005.03.005

Malik, M. A., Khan, I. A., Bhutto, S. A., \& Ghouri, A. M. (2011). Managerial skills and organizational learning in SMEs of Pakistan. Indian Journal of Commerce \& Management Studies, 2(4), 60-68.

Mansoor, Z. (2011). Football industry hub Sialkot struggles forward. Retrieved February 11, 2013, from http://dinarstandard.com/challenges/football-industry-hub-sialkot-struggles-forward-2/

McAdam, R., Armstrong, G., \& Kelly, B. (1998). Investigation of the relationship between total quality and innovation: a research study involving small organizations. European Journal of Innovation Management, 1(3), 139-147. http://dx.doi.org/10.1108/14601069810230216

Mody, A. (1993). Learning through alliances. Journal of Economic Behavior \& Organization, 20, $151-170$. http://dx.doi.org/10.1016/0167-2681(93)90088-7

Mone, M. A., McKinley, W., \& Barker, V. L. (1998). Organizational decline and innovation: a contingency framework". Academy of Management Review, 23(1), 115-132. 
Najib, M., \& Kiminami, A. (2011). Innovation, cooperation and business performance Some evidence from Indonesian small food processing cluster. Journal of Agribusiness in Developing and Emerging Economies, 1(1), 75-96. http://dx.doi.org/10.1108/20440831111131523

North, D., \& Smallbone, D. (2000). The Innovativeness and Growth of Rural SMEs During the 1990s. Regional Studies, 34(2), 145-157. http://dx.doi.org/10.1080/00343400050006069

Nunnally, J. C., \& Bernstein, I. H. (1994). Psychometric Theory. New York: McGraw-Hill.

O’Regan, N., Ghobadina, A., \& Sims, M. (2006). Fast tracking innovation in manufacturing SMEs. Technovation, 26, 251-261. http://dx.doi.org/10.1016/j.technovation.2005.01.003

Oboh, G. A. T. (2002, April). Bank participation in the promotion of small and medium-scale enterprises. Paper presented at the 6th Fellows and Associates Forum of CIBN.

Oke, A., Burke, G., \& Myers, A. (2007). Innovation types and performance in growing UK SMEs. International Journal of Operations \& Production Management, $27(7), \quad 735-753$. http://dx.doi.org/10.1108/01443570710756974

Okpara, F. O. (2000). Entrepreneurship (Text and Cases). Enugu, Nigeria : Precision Printers and Publishers.

Pedler, M., Burgoyne, J., \& Boydell, T. (1997). The Learning Company: A Strategy for Sustainable Development. Maidenhead: McGraw-Hill.

Popper, M., \& Lipshitz, R. (2000). Organizational learning: mechanism, culture and feasibility. Management Learning, 31(2), 181-196. http://dx.doi.org/10.1177/1350507600312003

Prajogo, D. I., Power, D. J., \& Sohal, A. S. (2004). The role of trading partner relationships in determining innovation performance: an empirical examination. European Journal of Innovation Management, 7(3), 178-186. http://dx.doi.org/10.1108/14601060410549874

Radas, S., \& Bozic, L. (2009). The antecedents of SME innovativeness in an emerging transition economy. Technovation, 29, 438-450. http://dx.doi.org/10.1016/j.technovation.2008.12.002

Ramezan, M. (2011). Intellectual capital and organizational organic structure in knowledge society: How are these concepts related? International journal of Information Management, 31(1), 88-95. http://dx.doi.org/10.1016/j.ijinfomgt.2010.10.004

Rosman \& Rosli. (2012). Small enterprises and the dilemma of malay entrepreneurs. Kuala Lumpur: University of Malaya

Rothwell, R. (1989). SMEs, inter-firm relationships and technological change. Entrepreneurship \& Regional Development, 1, 725-739.

Salavou, H. (2002). Profitability in market-oriented SMEs: does product innovation matter? European Journal of Innovation Management, 5(3), 164-171. http://dx.doi.org/10.1108/14601060210436736

Shan, W. (1990). An empirical analysis of organizational strategies by entrepreneurial high-technology firms. Strategic Management Journal, 11, 129-139. http://dx.doi.org/10.1002/smj.4250110205

Subrahmanya, M. H. (2005). Pattern of technological innovations in small enterprises: a comparative perspective of Bangalore (India) and Northeast England (UK). Technovation, 25, 269-280. http://dx.doi.org/10.1016/S0166-4972(03)00094-4

Tanvir, M. A., Rizvi, S., \& Riaz, W. (2012). Declining Market Share of Pakistan in Football Industry. Asian Journal of Business and Management Sciences, 1(11), 33-42.

Wale-Awe, O. I. (2002). Entrepreneurship Development (2nd ed.). Lagos, Nigeria: Gilgal Publications.

Wang, C. L., \& Ahmed, P. K. (2004). The development and validation of the organizational innovativeness construct using confirmatory factor analysis. European Journal of Innovation Management, 7(4), $303-313$. http://dx.doi.org/10.1108/14601060410565056

Weerawardena, J. (2003). The role of marketing capability in innovation-based competitive strategy. Journal of Strategic Marketing, 11(1), 15-35. http://dx.doi.org/10.1080/0965254032000096766

Wolf, J. A., \& Pett, T. L. (2006). Small-firm performance: Modeling the role of product and process improvements. Journal of Small Business Management, $44(2), \quad 268-284$. http://dx.doi.org/10.1111/j.1540-627X.2006.00167.x

Yap, C. M., Chai, K. H., \& Lemaire, P. (2005). An empirical study on functional diversity and innovation in SMEs. Creativity and Innovation Management, $146-190$. http://dx.doi.org/10.1111/j.1476-8691.2005.00338.x

\section{Copyrights}

Copyright for this article is retained by the author(s), with first publication rights granted to the journal.

This is an open-access article distributed under the terms and conditions of the Creative Commons Attribution license (http://creativecommons.org/licenses/by/3.0/). 